\title{
Case seminars open doors to deeper understanding Nursing students' experiences of learning
}

\begin{abstract}
Background
Creation of new knowledge is mainly accomplished by students themselves, and the main task of teachers in higher education is thus to facilitate this learning process. The Case Method is a teaching method in which cases from real life inspire students to actively seek knowledge that they discuss in structured seminars. Case seminars in health education have been evaluated, compared and discussed, but descriptions that can help us understand how students learn in the seminars have not previously been published. In a Swedish nursing programme, where case seminars have been used in teaching cardiovascular diseases for several years, students were asked to freely write down answers to three open questions concerning how the case seminars had helped them in their learning, what had been troublesome with the seminars, and whether they had any other comments on the seminars. The aim of the present study was to describe this learning process from the students' point of view.
\end{abstract}

\section{Methods}

Written data were analyzed using content analysis, which is a process of organizing and integrating qualitative information into themes, categories and codes.

\section{Findings}

A theme concerning how the Case Method opens doors to deeper understanding was identified as a thread running through different codes and categories. Students described the importance of new perspectives and their wish to participate in discussions with other students. The structure, which involved pre-prepared cases and writing on the white board, seemed to position the students' own knowledge in a wider context. This interest in reflective discussions and other students' different opinions indicate a deep approach to learning. To see if the findings reflected the participants' voice, the analysis with quotations, codes, categories and a theme was presented two years later to 62/69 students participating in the study. In a questionnaire after the presentation all agreed much or very much with the findings presented. To conclude the Case Method seems to involve students in a way that deepens their understanding and critical thinking.

\begin{tabular}{|c|c|c|}
\hline Codes & Category & Theme \\
\hline Different explanations & \multirow{4}{*}{$\begin{array}{l}\text { Learning together } \\
\text { through discussion }\end{array}$} & \multirow{12}{*}{$\begin{array}{l}\text { The Case Method opens doors to } \\
\text { deeper understanding }\end{array}$} \\
\hline Creative talks & & \\
\hline Knowledge is confirmed & & \\
\hline Making yourself heard & & \\
\hline White board writing is instructive & \multirow{4}{*}{$\begin{array}{l}\text { Learning together } \\
\text { with structure }\end{array}$} & \\
\hline The context becomes clear & & \\
\hline Cases make you ask new questions & & \\
\hline Cases encourage you to prepare & & \\
\hline There is no risk in asking questions & \multirow{4}{*}{$\begin{array}{l}\text { Learning together } \\
\text { with supervision }\end{array}$} & \\
\hline An open, enabling atmosphere & & \\
\hline Concern for students' learning & & \\
\hline Interest in knowledge & & \\
\hline
\end{tabular}

Figure. Codes, categories and a theme based on analysis of students' descriptions of experiences of learning in case seminars. 